\title{
Liveweight gain of lambs grazing three forage rapes which differ in total dry matter yield.
}

\author{
H.G. JUDSON, D.G. FERGUSON, M.K. CUTTS and A.J.E. MOORHEAD \\ Agricom, P.O Box 3761, Christchurch 8140
}

gjudson@agricom.co.nz

\begin{abstract}
Three forage rape cultivars ('Greenland', 'Spitfire' and 'Winfred') which differed in height and total dry matter production were compared in a lamb finishing system. Groups of lambs were rotationally grazed on one of three forage rape varieties over a period of 8 weeks in a four replicate trial. Lambs were allocated $2.5 \mathrm{~kg}$ dry matter $(\mathrm{DM}) /$ head/day in weekly breaks. Lambs were shifted and weighed weekly. 'Greenland' (tall) had a higher DM yield (10 vs 7.6 t DM/ha) and carried a higher stocking rate (75 vs 56 lambs/ha), but had a lower utilisation (46 vs 63\%) and supported a lower apparent intake (1.17 vs $1.45 \mathrm{~kg} \mathrm{DM} / \mathrm{h} /$ day $)$ and lamb growth rate (146 vs $205 \mathrm{~g}$ /day) compared with 'Winfred' (short). Fast lamb growth rates were associated with high intakes of mainly leaf but also high quality stem. Leaf percentage should be a key breeding objective for forage rape breeders and farmers need to consider attributes of forage rape cultivars other than just total dry matter yield.
\end{abstract}

Key words Forage rape, lamb, liveweight gain, dry matter yield, utilisation, quality

\section{Introduction}

Forage rapes (Brassica napus) are a common feed source for finishing lambs, particularly in summer dry environments. During summer, they can provide large volumes of high quality feed at a time when many grass-based pastures are either in their reproductive phase and are therefore of lower nutritive value, or have reduced dry matter (DM) production (White et al. 1999) because of low soil moisture and/or high environmental temperature and/or insect pressure. Further, forage rapes are an alternative to grazing old pasture potentially high in wild-type endophyte which affects lamb growth (Fletcher 1986). When forage brassicas crops are used in appropriate environments, lamb growth rates and stocking rates during the summer are typically higher than on grass-based pastures.

There are a number of commercially-available cultivars of forage rape (Stewart \& Charlton 2003). Although no formal distinction exists, it is generally considered cultivars fall into broad groupings depending on their height and regrowth ability.
Plant breeding decisions and rape cultivar selection by farmers are significantly influenced by potential DM yield, because livestock carrying capacity is predominantly determined by crop DM yield. However, on-farm anecdotal evidence suggests poor utilisation of high DM yielding crops can be an issue, and large post-grazing residual masses, consisting mainly of stem, are common. From these observations it is unclear whether selecting high DM yielding cultivars results in the most productive outcome from an animal performance viewpoint, particularly production perhectare. Understanding the effect of forage rape type on DM yield, utilisation and animal performance would be useful to farmers in selecting cultivars but also ensure plant breeding objectives are aligned with animal productivity targets.

The aim of this study was to compare the DM yield, utilisation and per lamb and per hectare performance from three forage rape cultivars differing in their height and total DM yield at their first grazing in a summer lamb finishing system.

\section{Methods}

The experiment was carried out across two sites simultaneously, with two replicates in Canterbury and a further two in Hawke's Bay, New Zealand. At each site, two tall forage rapes which differed in their development age (as determined by their first international Plant Variety Rights application date) ( $c v$ 'Greenland', 1997 and 'Spitfire', 2009) (Anon 2013) and a shorter rape ( $c v$ 'Winfred') were sown into an area of approximately $0.5 \mathrm{ha} /$ cultivar in spring (24 October) at a seeding rate of $4 \mathrm{~kg} / \mathrm{ha}$. Di-ammonium phosphate (DAP; $350 \mathrm{~kg} /$ ha) was broadcast prior to drilling and seed was treated with $12 \mathrm{ml} / \mathrm{kg}$ Gaucho $600 \mathrm{FS}$ insecticide (7.2 g a.i imidacloprid/kg seed, Bayer Crop Sciences). Each 0.5 ha area was divided in half to create replicates at each site to bring the total number of replicates per treatment to four. In each replicate, temporary fences were erected dividing the paddock into eight weekly grazing breaks. In mid-January, (83 days after sowing) mixed sex (Canterbury) or cryptorchid (Hawke's Bay) crossbred lambs (approximately $28 \mathrm{~kg}$ ) were placed in each paddock after being weighed. Animals were allocated to treatment groups based on liveweight so each group's 


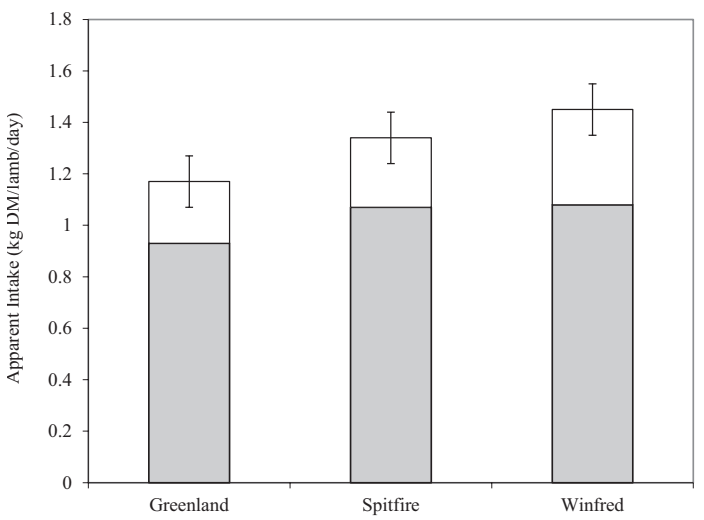

Figure 1 Apparent intake (kg DM/lamb/day) of leaf (grey) and stem (white) by lamb grazing three rape cultivars over eight weeks Bars represent SEM.

mean liveweight was similar, and stocked at a rate that achieved a daily crop DM allowance equivalent to 2.5 $\mathrm{kg} \mathrm{DM} / \mathrm{head} /$ day. Lambs were shifted and weighed weekly during the experiment. The number of lambs in each break at the beginning of the experiment and at the beginning of each subsequent week was determined by;

No. of lambs $=$ Pre-grazing crop mass (kg DM/ha) $\times$ break area (ha) Allowance $(\mathrm{kg} \mathrm{DM} / \mathrm{head} /$ day $) \times 7$ days

Pre-grazing crop mass in all plots was determined each week by cutting three quadrats (each $1 \mathrm{~m}^{2}$ ) to ground level and drying a sub-sample to constant weight at $85^{\circ} \mathrm{C}$. Post-grazing residuals were determined in the same way. The proportion of leaf (including petiole) and stem on plants was estimated by dissecting 10 plants in each plot prior to grazing in all treatments. Freshly harvested plants were weighed and subsequently dissected into leaf and petiole and stem. The stem was further dissected based on height into thirds. Sub-samples of leaf (with attached petiole) and each stem fraction were dried to constant weight at $65^{\circ} \mathrm{C}$ to determine dry matter percentage and for quality analysis. Metabolisable energy content of each component was determined by near-infrared spectroscopy after grinding samples through a 1 $\mathrm{mm}$ sieve. Apparent intake ( $\mathrm{kg} \mathrm{DM} / \mathrm{lamb} /$ day) was determined by dividing the differences between preand post-grazing yields by stocking rate for each break and the duration of grazing (seven days).

Treatment effects on crop yield, stocking rate, utilisation, liveweight gain and liveweight gain perhectare were analysed as a randomised complete block design with significant differences between means separated using a Duncan's Multiple Range test.

\section{Results}

Dry matter yields at first grazing varied from $7.6 \mathrm{t} \mathrm{DM} /$ ha to $10.2 \mathrm{t} \mathrm{DM} / \mathrm{ha}$ with associated stocking rates of 56-75 lambs per-hectare based on an average allowance of $2.5 \mathrm{~kg} \mathrm{DM} / \mathrm{lamb} /$ day (Table 1). The broad groupings based on height (tall and short) were justified based on observations in this trial and previous data collected in evaluation trials over 4 years (Table 1). Rape DM yields were consistent with expectations of type with tall rapes ('Greenland' and 'Spitfire') producing a higher DM yield than the shorter rape ('Winfred') (Table 1).

There were differences between rape cultivars in the proportion of leaf and stem in total plant DM (Table 2 ). The differences were confined to the proportion of leaf and lower stem where 'Greenland' had a lower proportion of leaf than 'Spitfire' (40 vs 50\%) but a higher proportion of lower stem (29 vs $21 \%$ ). The quality of stem was also different between rape types, with 'Winfred' and 'Spitfire' having a higher quality of mid and lower stem compared with 'Greenland'.

At a common DM allowance, crop utilisation varied from 46 to $63 \%$, was significantly different between 'Greenland' and 'Winfred', and was inversely proportionally to yield.

Table 1 Crop yield at grazing, stocking rate, intake parameters and liveweight gain (LWG) data for lambs on three rape cultivars.

\begin{tabular}{lllll}
\hline Cultivar & 'Greenland' & 'Spitfire' & 'Winfred' & LSD $_{0.05}$ \\
Type & Tall & Tall & Short & \\
\hline Yield & $10.2^{\mathrm{a}}$ & $9.5^{\mathrm{a}}$ & $7.6^{\mathrm{b}}$ & 1.4 \\
Crop height & $(\mathrm{cm})$ & $76^{\mathrm{a}}$ & $60^{\mathrm{b}}$ & 3.6 \\
Stocking rate (lambs/ha) & $75^{\mathrm{a}}$ & $71^{\mathrm{a}}$ & $56^{\mathrm{b}}$ & 10.3 \\
Utilisation & $46^{\mathrm{b}}$ & $55^{\mathrm{ab}}$ & $63^{\mathrm{a}}$ & 10.1 \\
Apparent intake (kg DM/head/day) & $1.17^{\mathrm{b}}$ & $1.34^{\mathrm{ab}}$ & $1.45^{\mathrm{a}}$ & 0.21 \\
Lamb liveweight gain (g/day) & $146^{\mathrm{b}}$ & $190^{\mathrm{a}}$ & $205^{\mathrm{a}}$ & 25.9 \\
Liveweight gain/ha (kg Lwt/ha/day) & $11.1^{\mathrm{a}}$ & $13.5^{\mathrm{a}}$ & $11.5^{\mathrm{a}}$ & 3.3 \\
\hline
\end{tabular}

*mean of four evaluation trials (2010, 2011, 2012 - Kimihia and 2012 -Culverden).

Within row, cultivar values with the same letter are not significantly different 
Mean daily apparent intake varied from 1.17 to 1.45 $\mathrm{kg} \mathrm{DM} / \mathrm{lamb} /$ day, which represented approximately $3.5-4.0 \%$ of average liveweight. Dissections of preand post-grazing samples allowed an estimate of the proportion of leaf and stem in daily apparent intake (Figure 1.) Lambs appeared to consume a greater proportion of leaf than stem. Relative to 'Greenland', higher apparent intakes on 'Winfred' were achieved by eating more leaf and stem.

Lamb liveweight gain reflected apparent DM intake (Table 1) ranging from 146 to $205 \mathrm{~g} /$ day and was significantly lower for 'Greenland' than the other rape cultivars. Liveweight production per ha (product of stocking rate and average lamb liveweight gain) tended to be greater for 'Spitfire' compared with both 'Greenland' and 'Winfred' (Table 1) but was not statistically significant.

\section{Discussion}

In this study, the rape cultivars producing the highest DM yield ('Greenland' and 'Spitfire') at first grazing generally had lower utilisation by lambs, although they did show variation in liveweight gain. The lower stem made up a greater proportion of total DM in 'Greenland', and the stem was of lower quality compared to 'Winfred' which had a lower DM yield and had less lower stem. Post-grazing residuals and estimates of apparent intake suggest these differences in plant composition were likely to be responsible for variation in intake and as a consequence lamb growth. Previous authors have reported similar effects (Armstrong 1984). In all treatments, leaf apparently made up the greatest proportion of lamb diets, but lamb intakes were in general higher where more leaf per lamb was on offer and/or when stem quality was high.

The DM yields and proportion of leaf of the different forage rape types in this experiment were consistent with reports from agronomic evaluation programs (PGG Wrightson \& Plant and Food, unpublished). Cultivars with high potential DM yield are likely to be taller and have a greater percentage of stem compared with cultivars of a lower total DM yield potential. Similar differences have been reported between giant and intermediate-stemmed kales (Judson \& Edwards 2008). This study further suggests that differences in stem proportions may be confined to the lower part of the stem. This study also identified that there was significant variation in the quality of stem. The data of Westwood \& Mulcock (2012) would further support this observation, with their whole plant metabolisable energy values differing by up to $0.7 \mathrm{MJ} \mathrm{ME} / \mathrm{kg} \mathrm{DM}$ between the cultivars used in the current study. Leaf proportion in this trial ( $c a .45 \%)$ was lower than that recorded by Westwood \& Mulcock (2012) (ca. 67\%). This might be expected because of the difference in crop age at evaluation, which was 98 DAS (Westwood \& Mulcock 2012) compared with 83 to 139 DAS in the present study, and a very favourable growing season resulting in high DM yields, and therefore taller stems. Improvements in leaf proportion across all treatments are likely to have improved utilisation, but this would not be expected to change rankings between types.

Forage rape cultivar had a significant effect on the apparent intake and liveweight gain of lambs when offered a common DM allowance. The rape cultivar which had the greatest proportion of leaf supported high liveweight gain per head, and despite carrying fewer animals per hectare had a numerically higher liveweight gain per hectare. This suggests tall types are not necessarily a problem if leaf proportion remains high. Given 'Spitfire's' later PVR date, this suggests modern plant breeding programs may already recognise this.

Lambs avoid grazing stem when allowances are generous, and this indicates that stem is not a preferred component of the diet regardless of quality. For example, 'Spitfire' had a stem of higher quality in the bottom two thirds compared to 'Greenland', but stem quality had no effect on intake under these allowances. If allowances were reduced and lambs forced to eat more of the stem, it is possible the difference in liveweight gain of lambs between 'Greenland' and 'Spitfire' might have been greater based on significant differences in stem quality.

For 'Greenland', intake by lambs appears to have been constrained, relative to the 'Winfred', by the apparent reluctance by lambs to consume stem. It is likely that intake and liveweight gain of lambs on 'Greenland' would have improved if allowances had been increased by reducing stocking rate, thereby increasing the amount of leaf on offer to each lamb. While this is a legitimate strategy for improving animal performance from varieties with a large proportion of stem, this strategy would negate any benefit of the higher potential DM yield, and further may heighten

Table 2 Proportion of leaf and petiole (leaf) and stem in each cultivar with associated nutritive value (MJME/kg DM)).

\begin{tabular}{|c|c|c|c|c|c|c|c|c|}
\hline \multirow[b]{2}{*}{ Type } & \multicolumn{4}{|c|}{$\%$ of total DM } & \multicolumn{4}{|c|}{ MJ ME/kg DM } \\
\hline & Greenland & Winfred & Spitfire & $\mathbf{L S D}_{0.05}$ & Greenland & Winfred & Spitfire & LSD $_{0.05}$ \\
\hline Leaf & $40^{b}$ & $44^{a b}$ & $50^{a}$ & 6.7 & $11.8^{\mathrm{a}}$ & $11.6^{a}$ & $12.0^{\mathrm{a}}$ & 0.99 \\
\hline Top & $12^{\mathrm{a}}$ & $15^{\mathrm{a}}$ & $12 a$ & 4.7 & $10.4^{\mathrm{a}}$ & $11.1^{\mathrm{a}}$ & $11.2^{\mathrm{a}}$ & 0.89 \\
\hline Mid & $19^{a}$ & $19^{a}$ & $17^{\mathrm{b}}$ & 1.5 & $8.9^{b}$ & $10.7^{a}$ & $11.0^{\mathrm{a}}$ & 0.96 \\
\hline Bottom & $29^{a}$ & $22^{b}$ & $21^{b}$ & 4.6 & $7.1^{\mathrm{b}}$ & $10.1^{a}$ & $10.4^{a}$ & 1.37 \\
\hline
\end{tabular}


issues around removing remaining stem residuals prior to subsequent renovation and re-grassing.

Increasing utilisation of a forage crop is often seen as a strategy of improving overall farm system efficiency. However, Judson \& Parris (2007) and Judson (2010) have highlighted the need to optimise utilisation rather than maximise it in order to achieve maximum liveweight gain per hectare. However, this experiment has highlighted that particularly for stemmed brassica, optimal utilisation may be different for different cultivars based on their leafiness and potentially the quality of stem.

The differences between rape types in crop utilisation (at the same allowance) and lamb growth rate has significant implications for the development of new cultivars. Where future breeding lines are evaluated solely on potential DM yield it is likely lines with a high proportion of stem will be ranked highly. This study suggests this would be potentially to the detriment of animal performance. Selections for leaf proportion and stem quality (particularly upper stem) are likely to be more beneficial to summer lamb finishing systems.

\section{ACKNOWLEDGEMENTS}

The authors acknowledge Hamish Best and Brent Macaulay for technical assistance.

\section{REFERENCES}

Anonymous. 2010. UPOV International Union for the Protection of new varieties of plants Pluto: Plant variety database. Accessed: 9 September 2013. https://www3.wipo.int/pluto/user/en/index.jsp
Armstrong, R.H. 1984. The structure of the rape crop (Brassica napus) and its effect on intake by lambs. pp. 72-76 In: Proceedings of "Better Brassicas '84" Conference, St Andrews 1984 Eds. McFarlaneSmith, W.H.; Hodgkin, T. Scottish Crop Research Institute, Dundee.

Fletcher, L.R. 1986. Lolium endophyte and sheep performance on perennial ryegrass cultivars. Proceedings of the New Zealand Grasslands Association 47: 99-105.

Judson, H.G. 2010. Maximising productivity from Brassica crops. pp. 96-99 In: Proceedings of the 25th Annual Conference of the Grasslands Society of NSW.

Judson, H.G.; Parris, M.A. 2007. Optimising lamb production on summer crops. pp. 2935 In: Proceedings 37th Seminar Society of Sheep Beef Cattle Veterinarians, New Zealand Veterinary Association.

Stewart, A.V.S; Charlton, D. 2003. Pasture and forage plants for New Zealand. Grassland Research and Practice Series 8 (3rd Edition): 100-101.

Westwood, C.T.; Mulcock, H. 2012. Nutritional evaluation of five species of forage brassica Proceedings of the New Zealand Grassland Association 74: 31-38.

White, J.G.H.; Mathew, C.; Kemp, P.D. 1999. Supplementary feeding systems. pp. 175-197 In: New Zealand pasture and crop science. Eds. White, J.; Hodgson, J. Oxford University Press. 